\title{
GENDER AND TEACHER EXPERIENCE AS DISTINGUISHING FACTORS OF CLASSROOM INTERACTION PATTERN OF TEACHERS OF TWO MODES OF STUDY IN SOCIAL STUDIES CLASS
}

\section{EUGENIA A. OKWILAGWE (PhD) AND JANET O. ADETAYO (PhD)}

\begin{abstract}
The study investigated the interaction pattern of primary school Social Studies teachers. Purposive sampling procedure was used to select 40 NTI NCE and 40 full-time NCE teachers who teach at the middle basic in Ogun State, Nigeria. A valid and reliable instrument, the Classroom Interaction Sheet (CIS)(a ranging from 0.70-0.85) was used to obtain classroom coded behaviours of these teachers. Data were analysed using descriptive, t-test and ANOVA statistics. NTI NCE teachers and full-time NCE teachers did not facilitate active learning activities in the classroom as 10.3 and 10.4 minutes respectively were spent facilitating learning, whereas pupils under the two types of teachers spent 4.2 minutes or about $29 \%$ of class time respectively participating in learning activities. NTI NCE and full-time NCE teachers spent 6.27and6. 21 minutes respectively on monologue and other activities that did not facilitate learning. Teacher's experience and gender did not significantly distinguish between teacher interactions patterns in Social Studies class. In view of these results, it was recommended that there is a compelling need for Social Studies trainee teachers to be well grounded in sound pedagogy that will enable them exhibit innovativeness and ingenuity in class. Also, teacher preparation during teaching practice should not be left exclusively to Colleges/Faculties of Education but should be a collaborative effort among host and external auditing personnel, Ministry of Education, school heads and other teacher representatives in the state.
\end{abstract}

Key words: Classroom interaction pattern, Social Studies, Gender, NTI NCE programme, Distance learning programme.

\section{Introduction}

The consistent poor academic achievement of students in school and particularly in externally conducted examinations such as those conducted by WAEC and NECO has and is still generating lots of concern and debate on the way forward in the education arena in Nigeria. As these debates and concern go on, the situation has informed many research efforts aimed at diagnosing the problem. These include those of Ajewole (1993), Akinwumiju and Orimoloye (1997), Labo-Popoola (2002), Adeniji (2003), Oloyede and Amusuro (2006), Ojo (2006) and Akpan (2008). The outcome of these and many other works advanced many reasons for the poor academic achievement of secondary school students in these examinations to include teacher quality, school and student factors and pedagogic inadequacies. In spite of these efforts, the situation has not witnessed any appreciable change. These current researchers are of the view that the process and effectiveness of instructional delivery is a very crucial factor to effective student learning and success in any examination, irrespective of the inadequacies of inputs applied to learning situations.

According to Oloyede and Amusuro (2006), a teacher is the bridge that makes teaching and learning effective. The teacher can be likened to a builder whose performance depends on adequate knowledge, qualification, experience and preparation. Teaching according to Oyekan (2000) is a continuous human activity by which the teacher connects the learner and the subject matter drawn from the school curriculum. Teaching is done systematically by a teacher who has acquired some skills either by training or by 
experience or both. To make the desirable impact, teaching must aim at the total development of the individual, that is, to enhance intellectual capabilities, foster psychosocial skills, and draw out neuro-physical aptitudes of the learners (Ogunyemi, 2000). Therefore, the goals of effective teaching according to Ebong (2006),should:

(i) enable the learner develop his or her potentials; (ii) contribute to thinking in the subject; (iii) sustain students' interest; (iv) suit the circumstances of teaching learning; and (v) suit the individual teacher's ability and interest.

Besides, teachers have a central role to play in the implementation of the Social Studies curriculum. In the views of Arends (1991), an effective teacher should have a solid knowledge base, versed in a repertoire of pedagogical practices, have attitudes and skills for reflection and problem solving, and see learning to teach as a lifelong process. Also, according to Ezeasor (2005), he/she should rely on his/her classroom interactions with the students to gauge the level of effectiveness and pace of instruction. Arguing in the same vein, Okwilagwe and Samuel (2011) contend that in specific terms, an effective teacher should use instruction to inspire, stimulate and encourage learners to assimilate instructional contents, as well as encourage them to actively participate in classroom activities and, do more take-home assignments in order to produce high cognitive and affective outcomes in them. It follows, therefore, that it is not possible to guarantee a successful or meaningful learning of Social Studies in schools without effective teachers to translate the laudable objectives of Social Studies education into practice through appropriate classroom behaviours.

Classroom interaction study is a new wave of research approach to studying teaching and learning activities rather than limiting such researches to the manipulation or studying of antecedents and consequences. With such attention being focused at the classroom on how the teacher actually teaches and pupils actually learn, more insights are gained on the communication and frequency of such communications in the classroom. In the views of Oyedeji (1993), the general acceptance about classroom interaction patterns of a teacher is that they play an important role in the development of pupils' understanding, recognition and establishment of the teachers' effectiveness in teaching. Falaye (2007) gives credence to the need of such interactions by affirming that observation and analysis of classroom interactions using systematic instruments are of considerable importance in the educational scene, even though there is paucity of observation studies in Nigeria. When compared with studies on other aspects of education, interest in the use of observational techniques is no doubt mounting. In her views, information derived from classroom interaction analysis serves as a useful feedback into the system and for decision-making. Also, Onocha and Okpala (1995) further affirm that the applicability of systematic observation in a natural setting is an important advantage of this approach.

Classroom interaction analysis is a systematic quantification of behavioural acts as they occur in some sort of spontaneous interaction (Flanders, 1970). The concept of classroom interaction refers to the chain of events which occur one after the other, each occupying a small segment of time. Studies in classroom observation are, therefore, a way to bridge the gap between the teacher's good intentions for the class and the behaviour which actually occurs in the classroom (Flanders, 1970). The classroom verbal interaction pattern created by a teacher has become an important factor in the teaching-learning process and therefore, it should be identified and utilised for optimal learning. Till very recently, almost all attempts to analyse classroom interaction in Nigeria and elsewhere 
were based on Flanders 'Interaction Analysis Categories System (Yoloye, 1977; Okpala \& Onocha, 1988; Oyedeji, 1993; Isiugo-Abanihe, 2004; Falaye, 2007; Akpan, 2008; Babelan \& Kia, 2010). The beauty of this study is the use of the Classroom Interaction Sheet (CIS) that is gradually gaining acceptance as a valid and reliable instrument for capturing teacher behaviour in the classroom. The Classroom Interaction Sheet (CIS) is a category system, in which observations are made for a few seconds. It provides a moving picture of the classroom interaction during the observation period and it also provides the frequency of occurrence and time during which the behaviour occurs (Onocha \& Okpala, 1995). One major edge the CIS has over the Flanders FIACS (though both are category systems) is the time dimension. The 'time on task' that the teacher expends on every class activity particularly on student's learning activities vis- $\dot{a}$-vis 'time off task' etc. is crucial in understanding the quality of learning behaviour provided in such classes that enhances effective learning and achievement of success. This is what Carroll 1963 called ALT (Academic Learning Time).

The concern of this study is that not much is known about what actually takes place inside our Social Studies classrooms since most previous researches on what accounts for the variance in students' achievement have concentrated primarily on inputs and outputs of the educational activities with little attention paid to intervening process activities (Akpan, 2008). If much of the teaching time is used by Social Studies teachers in soloperformance or in managing classroom problems, effective teaching and learning cannot be guaranteed. It thus becomes very necessary to find out what actually happens in Social Studies classroom at the primary school level in Ogun State in order to identify problems encountered by the teachers in the teaching and learning process and be able to proffer appropriate solutions.

Social Studies is a dynamic school subject and by virtue of its integrated nature and philosophy, it is highly affective and value-laden (Nwaubani, 2005). Hence, it is necessary to examine what goes on in Social Studies classroom with a view to assessing its efficacy in promoting the objectives of Social Studies education in Nigeria (Falaye, 2007). The role of promoting simultaneously the three domains of learning in order to achieve the education of the complete man distinguishes Social Studies content from other subjects and by implication imposes on its teaching and learning those instructional methods, activities and experiences that provide social and intellectual skills, positive attitudes, values and cognitive development (Mkpa, 1997). To achieve these, therefore, the Social Studies teacher is expected to encourage open and permissive classroom interactions. This is the whole idea behind functional and resource-based teaching methods and practices which are fundamental to the effective teaching and learning of integrated Social Studies in Nigerian schools (Federal Ministry of Education, 2007; Federal Republic of Nigeria, 2004).

Teacher gender and experience are two factors that educators think should positively influence teacher effectiveness. However, previous studies in respect of these factors have reported mixed findings. With respect to gender, the term has been construed to mean the characteristics by which male and female people are defined. These characteristics, therefore, tend to suggest that male and female differ in their physical, emotional and intellectual development (Awoyemi, 2000). The notion that certain types of teachers might be more effective in teaching certain types of subject matter has been an issue of concern in education research. For instance, Ogunkola (1999) reported that male teachers differ significantly from their female counterparts in instructional process and the amount 
of whole class initiated interactions in science classes. However, studies such as those of Brophy (1999) and Kiadese (2011) tend to debunk any gender difference in teaching effectiveness or class interactions. Teacher's experience has been found to influence teachers' performance especially after they have spent some duration of time in the teaching profession while others did not find any difference. For instance, in a study comparing the teaching style of experienced and inexperienced male and female teachers, Bress (2000) found that experienced male and female teachers are more efficient than the inexperienced teachers whose teaching became more efficient over time. However, concerning experience, he found that male teachers tended to ignore problems more or engage in over detailed learning style when teaching, while the female teachers provided not too clear instructions. In the Oloyede and Amosuro's (2006) study, teacher's experience was found to negatively influence teachers' performance in the classroom. In this study, the need arises, therefore, to further explore the influence of these factors on teacher interaction behaviours to determine their role in the teaching process since their influence in the classroom is inconclusive.

In spite of the social, cultural, economic and educational values of Social Studies in Nigeria's search for national and global identity as a nation, students' achievement in the subject shows growing decline in Junior Secondary Certificate Examination (JSCE) in some states of the country (Yusuf, 2004). Social Studies educators such as Linda (2000), Mezeiobi (2000) and Yusuf (2004), giving reasons for the poor achievement of students in the subject, alluded to the quality and attitudes of teachers. Also, Falaye (2007) using the Flanders' Interaction Analysis Categories in her study reported that the teacherdominated conventional method of teaching still pervades the classrooms. In view of the foregoing and the paucity of empirical work on classroom interaction pattern in Social Studies classroom, this study set out to investigate Social Studies teachers' classroom interaction pattern at the primary school level in Ogun State, Nigeria to establish if group differences exist in terms of teacher's gender and experience in their interaction process.

\section{Research Questions}

In this study, the following questions were examined.

1. What is the classroom interaction pattern of NCE primary school Social Studies teachers in Ogun State?

2. Is there a significant group difference in the interaction pattern of these teachers in terms of gender and experience?

\section{Methodology}

\section{Research Design}

This study is a non-experimental survey research. In the survey type of research, the researcher does not manipulate any of the variables, since they have all occurred in time. However, a post-test only comparable group was built into the study with the purpose of comparing and making authentic inference about the interaction patterns of the NTI NCE teachers' instructional competence. 


\section{Target Population}

The target population for the study comprised all graduates of the NTI (NCE) programme as well as other NCE graduates from regular Colleges of Education in the country who teach at the primary schools in Ogun State of Nigeria.

\section{Sampling Technique and Sample}

The study adopted a multi-staged sampling technique. The twenty local government areas in the State were stratified into four zones namely, Egba; Yewa; Ijebu and Remo, from which two Local Government Areas per zone were randomly selected to give a total of eight. Random sampling was used to select two Social Studies teachers(one a product of NTI and the other a product of a regular NCE institution, who teach at the middle basic classes primary 4 to 6 ) in each of the selected schools. This was done after an initial visit to the schools to ascertain the type of teacher present.

\section{Instrumentation}

The Classroom Interaction Sheet (CIS) adapted from Okpala and Onocha (1988) and Odinko and Williams (2006) was used to observe the NCE graduate teachers and the comparable group in their various classrooms to determine their instructional competence. The instrument has three major categories and eleven sub-categories arranged in such a format that allows recorded behaviours to reflect the sequence of occurrence as well as its frequency. The three major categories of the instrument are: 'teacher facilitating learning', 'pupils' activity' and 'teacher not facilitating learning'. The instrument has high inter-rater (0.87-0.93) and intra-rater (0.83-0.91) reliability values as reported by Okpala (1999). The instrument has been used in a number of studies that evaluated teaching effectiveness in Nigerian schools. For the purpose of this study, the researchers re-established the reliability of the instrument by observing thirty (30)teachers and the inter-rater and intra-rater reliability using Scots $\pi$ yielded values of between $0.76-$ 0.85 .

\section{Data Collection and Analysis}

Collection of data involved four other research assistants who are trained in the use of observation techniques. The process required that the observer be physically present in the classroom throughout the observation period. Data was analysed using descriptive (frequency counts, percentages) and t- test statistics.

\section{Results}

Observed classroom interaction pattern of NTI NCE- trained teachers using Classroom Interaction Sheet (CIS) is presented Table 1.The forty NTI NCE trained teachers spent a total of 7 hours, 29 minutes, 35 seconds $(2,111$ tallies) facilitating learning out of the total observation time of 13 hours and 30 minutes (4,083 tallies). On the average, each teacher spent 10.3 minutes out of a total time of 20.40 minutes observation time facilitating learning. Of this amount of time, 4 minutes were spent explaining concepts, 3 minutes and 2 seconds were used for questioning and 2 minutes spent writing on the chalkboard. About 58 seconds and 43 seconds respectively were used for reinforcement of correct responses and demonstrating with materials while 9 seconds were spent giving directives. 
The total time spent by pupils participating in the entire teaching-learning process was 2 hours 52 minutes and 3 seconds (or 773 tallies).

Table 1: Observed Classroom Interaction Pattern of NTI NCE Trained Teachers

\begin{tabular}{|c|c|c|c|c|c|c|c|c|}
\hline$/ \mathrm{N}$ & $\mathrm{C}$ a t e g o r y & Yo. of Itllies Ifma.1 & & asiolin & Lis py induli & 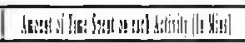 & 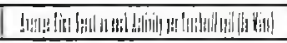 & Total Alertage Pescentass \\
\hline $\mathrm{A}$ & $\begin{array}{llllllll} & \mathrm{e} & \mathrm{a} & \mathrm{c} & \mathrm{h} & \mathrm{e} & \mathrm{r}\end{array}$ & $\begin{array}{lll}F & a & c \\
\end{array}$ & $T$ & $\mathrm{i} t$ & $a t \quad i$ & L $\quad$ e $a$ & $\mathrm{n} i \mathrm{n} g$ & $\begin{array}{lllll} & \mathrm{i} & \mathrm{i} & \mathrm{t} & \mathrm{y} \\
\end{array}$ \\
\hline 1 & Writing on the chalkboard & 4 & 1 & & $\overline{0}$ & $\begin{array}{lccc}8 & 0 \\
\text { (mins) }\end{array}$ & $2.00(\mathrm{mins})$ & $\begin{array}{lllll} & 0 & . & 0 & 2\end{array}$ \\
\hline 2 & Demonslıatinẹ wilł malesials & 8 & 2 & & & $\begin{array}{cccc}\begin{array}{c}7 \\
\text { (mins) }\end{array} & \cdot 2 & 4 \\
\end{array}$ & $0.43 \quad(\mathrm{secs})$ & 1 \\
\hline 3 & Explaindng & 8 & 2 & & 1 & $\begin{array}{lllll}16 & 61 \\
\text { (mins) } & & 8 & 4 \\
\end{array}$ & $4.05(\mathrm{mins})$ & $\begin{array}{lllll}2 & 0 & . & 2 & 3\end{array}$ \\
\hline 4 & Questioning & 65 & 1 & & 6 & $\begin{array}{l}127 \\
\text { (mins) }\end{array}$ & $8(\mathrm{mins})$ & 15 \\
\hline 5 & Giving directives & 2 & 1 & & & $3.92(\mathrm{mins})$ & $0.10 \quad(s \in c s)$ & 4 \\
\hline 6 & Reinforcing correcl response & 8 & 2 & & & $23.12(\mathrm{mins})$ & $0.58(s \in c s)$ & 2 \\
\hline & $t \circ 0 \quad t a l$ & 2,111 & 5 & & 2 & 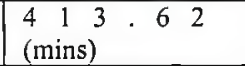 & 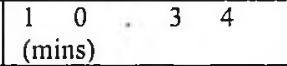 & $51.70 \%$ \\
\hline $\mathrm{B}$ & $\mathrm{P}$ & $\mathrm{i}$ & I & $\underline{s}$ & & A & $\mathrm{v}$ & $y$ \\
\hline 7 & $R$ e c i t i n $g$ & 1 & 4 & & & $30.37(\mathrm{mins})$ & $0.76(\mathrm{mins})$ & 3 \\
\hline 8 & Responding & $\begin{array}{ll}6 & 1\end{array}$ & 1 & & 5 & $\begin{array}{llllll}1 & 2 & 1 \\
\text { (mins) }\end{array}$ & $3.02(\mathrm{~m} \mathrm{i} \mathrm{ns})$ & $\begin{array}{lllll}1 & 5 & . & 1 & 3\end{array}$ \\
\hline & $\begin{array}{lllll}t & 0 & t & a & 1\end{array}$ & 7 & 1 & & 9 & $\begin{array}{llll}1 & 5 & 1 \\
\text { (mins) }\end{array}$ & $\begin{array}{l}3 \\
\text { (mins) }\end{array}$ & $\begin{array}{llllll}1 & 8 & 9 & 3 & \%\end{array}$ \\
\hline $\mathrm{C}$ & $\begin{array}{llllll} & a & c & h & e & r\end{array}$ & $0 \mathrm{t}$ & $\mathbf{c}$ & $\mathrm{i} \quad \mathrm{l}$ & $i t a$ & $\mathrm{i} \mathrm{ng}$ & $\begin{array}{lllll}\mathrm{r} & \mathrm{n} & \mathrm{i} & \mathrm{n} & \mathrm{g}\end{array}$ & i $v$ i t $t y$ \\
\hline 9 & Teachet lalking nonestop & 1,013 & 2 & & 5 & 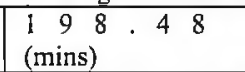 & $4.96(\mathrm{~m} \mathrm{i} \mathrm{n} \mathrm{s})$ & 24 \\
\hline 0 & $\begin{array}{lllllll}S & \mathrm{i} & \mathrm{l} & \mathrm{e} & \mathrm{n} & \mathrm{c} & \mathrm{e} \\
\end{array}$ & 0 & 5 & & & $35.27(\mathrm{mins})$ & $0.88(\mathrm{~m} \mathrm{i} \mathrm{n} \mathrm{s})$ & 4 \\
\hline 1 & Attending to visitor & 6 & 1 & & & $1.17(\mathrm{mins})$ & $0.03(\mathrm{mins})$ & 0 \\
\hline & $t \circ 0^{\prime} \mathrm{al}$ & 1,199 & 3 & & 1 & $\begin{array}{lll}2 & 34 \\
\text { (mins) }\end{array}$ & $5.87(\mathrm{~m} \mathrm{ins})$ & $209.36 \%$ \\
\hline & Grand Total & 4.083 & & $\underline{0}$ & 2 & $800(\mathrm{mins})$ & $20.40(\mathrm{mins})$ & $\%$ \\
\hline
\end{tabular}

On the average, the pupils recited for 1 minute and 15 seconds and provided responses to teachers' questions for about 3 minutes. Table la further reveals that 4 hours 31 minutes and 53 seconds (1,199 tallies) were spent by the teachers not imparting active learning. On the average, each NTI NCE teacher spent a total of 54 minutes (31tallies) not facilitating learning. Out of these, 4 minutes and 25 seconds was used by each teaching talking non-stop; amount of silence observed within the entire teaching period was about 1 minute, 27 seconds while 2 seconds was used in attending to visitors.

Table 2: Observed Classroom Interaction Pattern of Full-time NCE-Trained Teachers

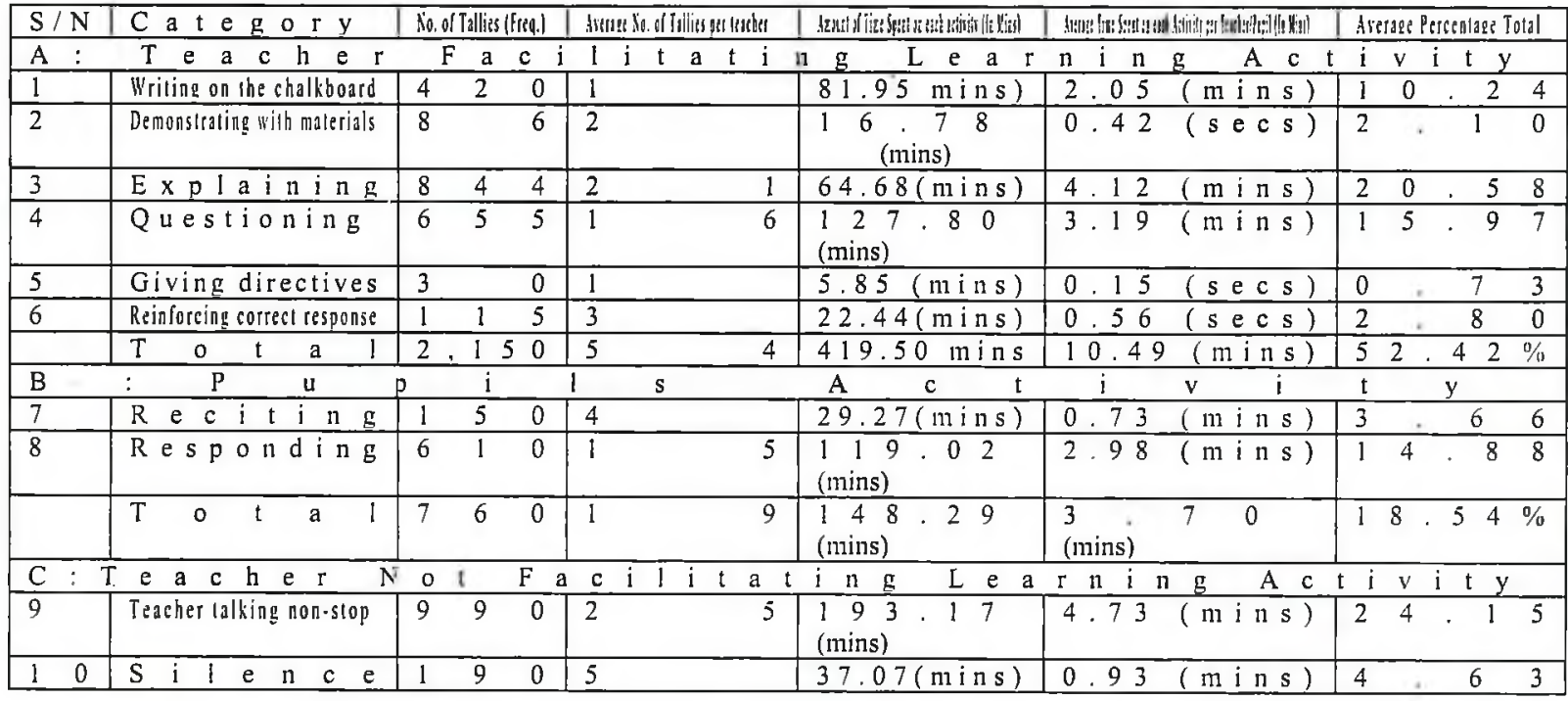




\begin{tabular}{|c|c|c|c|c|c|c|c|}
\hline 11 & Attending to visitor & 1 & & & $(\mathrm{mins})$ & $0.05 \quad(\mathrm{~s} e \mathrm{cs})$ & 0 \\
\hline & $\mathrm{T}$ & 1,190 & 3 & 0 & $\begin{array}{lllll}2 & 32 \\
\text { (mins) }\end{array}$ & $\begin{array}{llll}5 & 8 & 1 \\
\text { (mins) }\end{array}$ & $36 \%$ \\
\hline & Grand Total & 4,1100 & 1 & 0 & $800(\mathrm{mins})$ & $20.40(\mathrm{mins})$ & 0 \\
\hline
\end{tabular}

The 40 full-time NCE trained teachers as presented in Table 2,spent 7 hours 39 minutes and 19 seconds $(2,150$ tallies) facilitating learning out of the total observation time of 13 hours and 30 minutes (or 4,100 tallies). On the average, this means that about 10 minutes of the observation time of 20 minutes were spent facilitating learning. Of this amount of time, 4minutes and 11 seconds was used in explaining, 3 minutes and 19 seconds were used for questioning and about 2 minutes spent writing on the chalkboard. Also, 55 seconds were spent on reinforcement of correct responses, 41 seconds on demonstrating with materials and 15 seconds giving directives. The total time spent by pupils participating in the entire teaching-learning process was 2 hours 47 minutes and 15 seconds (or 760 tallies). On the average, the pupils recited for 1 minute 13 seconds and provided responses to teachers' questions for 3 minutes 7 seconds. Four hours 27 minutes and 39 seconds (1,190 tallies)were spent not imparting active learning by the teachers. On the average, each full-time NCE teacher spent a total of 5 minutes and 36 seconds not facilitating learning. Out of these, 4 minutes and 15 seconds were used talking non-stop, observed silence was 1 minute and 16 seconds while 5 seconds were used in attending to visitors (Refer to Table 2).

Table 3: T-test Analysis of Classroom Interaction of NTI NCE and Full-time NCE Teachers by Years of Experience

\begin{tabular}{|c|c|c|c|c|c|c|c|c|}
\hline Behaviour category & Years of Experience & Mode of Study & $\mathrm{N}$ & Mean & S.D & t-value & $\mathrm{df}$ & P.value \\
\hline \multirow[t]{3}{*}{ Teacher facilitating le } & $1-5$ years & $\begin{array}{l}\text { NTI NCE } \\
\text { Full Time }\end{array}$ & $\begin{array}{l}7 \\
5\end{array}$ & $\begin{array}{l}53.43 \\
54.20\end{array}$ & $\begin{array}{l}10.64 \\
6.50\end{array}$ & 0.143 & 10 & $0.889 \mathrm{NS}$ \\
\hline & $6-10$ years & $\begin{array}{l}\text { N T I NCE } \\
\text { Full Time }\end{array}$ & $\begin{array}{ll}1 & 5 \\
7 & \end{array}$ & $\begin{array}{l}52.60 \\
55.71\end{array}$ & $\begin{array}{l}7.85 \\
9.84\end{array}$ & 0.800 & 20 & $0.433 \mathrm{NS}$ \\
\hline & Above 10 years & $\begin{array}{l}\text { NTI NCE } \\
\text { Full Time }\end{array}$ & $\begin{array}{l}18 \\
28\end{array}$ & $\begin{array}{l}52.56 \\
53.18\end{array}$ & $\begin{array}{l}11.86 \\
10.73\end{array}$ & 0.184 & 44 & $0.855 \mathrm{NS}$ \\
\hline \multirow[t]{3}{*}{ Pupils activities } & $1-5$ years & $\begin{array}{l}\text { NT I NCE } \\
\text { Full Time }\end{array}$ & $\begin{array}{l}7 \\
5\end{array}$ & $\begin{array}{l}22.29 \\
19.80\end{array}$ & $\begin{array}{l}5.79 \\
4.27\end{array}$ & 0.811 & 10 & $0.436 \mathrm{NS}$ \\
\hline & $6-10$ years & $\begin{array}{l}\text { N T I N CE } \\
\text { Full Time }\end{array}$ & $\begin{array}{ll}1 & 5 \\
7 & \end{array}$ & $\begin{array}{l}18.47 \\
16.14\end{array}$ & $\begin{array}{l}6.66 \\
6.47\end{array}$ & 0.769 & 20 & $0.451 \mathrm{NS}$ \\
\hline & Above 10 years & $\begin{array}{l}\text { N T I NCE } \\
\text { Full Time }\end{array}$ & $\begin{array}{l}18 \\
28\end{array}$ & $\begin{array}{l}18.89 \\
19.50\end{array}$ & $\begin{array}{l}7.72 \\
7.56^{72}\end{array}$ & 0.265 & 44 & $0.792 \mathrm{NS}$ \\
\hline \multirow[t]{3}{*}{ Teacher not facilitating learning } & $1-5$ years & $\begin{array}{l}\text { N T I NCE } \\
\text { Full Time }\end{array}$ & $\begin{array}{l}7 \\
5\end{array}$ & $\begin{array}{l}33.43 \\
26.60\end{array}$ & $\begin{array}{l}10.08 \\
2.19\end{array}$ & 1.471 & 10 & $0.177 \mathrm{NS}$ \\
\hline & $6-10$ years & $\begin{array}{l}\text { N T I NCE } \\
\text { Full Time }\end{array}$ & $\begin{array}{ll}1 & 5 \\
7 & \end{array}$ & $\begin{array}{l}30.13 \\
30.00\end{array}$ & $\begin{array}{l}6.28 \\
5.45\end{array}$ & 0.048 & 20 & $0.962 \mathrm{NS}$ \\
\hline & Above 10 years & $\begin{array}{l}\text { N T I N CE } \\
\text { Full Time }\end{array}$ & $\begin{array}{l}18 \\
28\end{array}$ & $\begin{array}{l}28.50 \\
30.50\end{array}$ & $\begin{array}{l}4.87 \\
5.95\end{array}$ & 1.195 & 44 & $0.238 \mathrm{NS}$ \\
\hline
\end{tabular}

NS $=$ Not Significant at $\mathrm{p}<0.05$

There is no significant difference in the NTI NCE teachers and full-time NCE teacher's classroom behaviours based on years of experience and gender (Refer to Table 3 and 4). 
Table 4: T-test Analysis of Classroom Interaction of the NTI NCE and Full-time Teachers by Gender

\begin{tabular}{|c|c|c|c|c|c|c|c|c|}
\hline Behavior category & Gender & Mode of Study & $\mathrm{N}$ & Mean & S.D. & t-value & $\mathrm{df}$ & P.value \\
\hline \multirow{3}{*}{ Teacher facilitating lea } & $\mathrm{M}$ a $\mathrm{Ie}$ & NTI NCE & 4 & 52.25 & 11.87 & & & \\
\hline & & Full Time & & 62.67 & 11.15 & -1.177 & 5 & $0.292 \mathrm{NS}$ \\
\hline & Female & $\begin{array}{l}\text { N T I N C E } \\
\text { Full Time }\end{array}$ & $\begin{array}{ll}3 & 6 \\
37 & \\
\end{array}$ & $\begin{array}{l}52.78 \\
53.03 \\
\end{array}$ & $\begin{array}{l}10.02 \\
9.70 \\
\end{array}$ & -0.108 & 71 & $0.914 \mathrm{NS}$ \\
\hline \multirow[t]{2}{*}{ Pupils activities } & $\mathrm{M}$ a $1 \mathrm{e}$ & $\begin{array}{l}\text { NT I NCE } \\
\text { Full Time }\end{array}$ & $\begin{array}{l}4 \\
3\end{array}$ & $\begin{array}{l}21.50 \\
14.33\end{array}$ & $\begin{array}{l}4.65 \\
3.79\end{array}$ & 2.168 & 5 & $0.082 \mathrm{NS}$ \\
\hline & Female & $\begin{array}{l}\text { N T I N C E } \\
\text { Full Time }\end{array}$ & $\begin{array}{ll}3 & 6 \\
37 & \end{array}$ & $\begin{array}{l}19.08 \\
19.33\end{array}$ & $\begin{array}{l}7.22 \\
7.14\end{array}$ & -0.143 & 71 & $0.886 \mathrm{NS}$ \\
\hline \multirow[t]{2}{*}{ Teacher not facilitating } & $\mathrm{Male}$ & $\begin{array}{l}\text { N T I N C E } \\
\text { Full Time }\end{array}$ & $\begin{array}{l}4 \\
3\end{array}$ & $\begin{array}{l}30,50 \\
30.00\end{array}$ & $\begin{array}{l}5.32 \\
4.00\end{array}$ & 0.135 & 5 & $0.898 \mathrm{NS}$ \\
\hline & Female & $\begin{array}{l}\text { N T I N C E } \\
\text { Full Time }\end{array}$ & $\begin{array}{ll}3 & 6 \\
37 & \\
\end{array}$ & $\begin{array}{l}29.92 \\
29.92\end{array}$ & $\begin{array}{l}6.75 \\
5.74 \\
\end{array}$ & -0.002 & 71 & $0.999 \mathrm{NS}$ \\
\hline
\end{tabular}

NS $=$ Not Significant at $\mathrm{p}<0.05$

\section{Discussion}

There is a clear indication from the findings in this study that most of the primary school teachers still dominate classroom activities and learning of content at the expense of students' active participation in the lesson. This conclusion is derived from the very low percentages obtained under pupils' activities, an average of $(18.93 \%)$ or (4 mins. 19 seconds) for NTI NCE teachers and $(18.54 \%$ ) or (4 minutes 11 seconds) for Full-time NCE teachers. This observation is further buttressed by the amount of time the teachers talked non-stop (monologue); and explained content to the pupils, 5 minutes on the average out of the 20 minutes observation time for both the NTI NCE teachers and fulltime NCE teachers. This implies that for most part of the lessons observed, the pupils were passive spectators since majority of the teachers' still use lecture and/or other poor classroom teaching methods to a very large extent in their instruction. This also means that with continuous teacher dominance in instructional activities in primary school classrooms, the more the pupils are discouraged from demonstrating personal initiatives, a situation that could engender difficulties in contributing to classroom discussion and in learning. This finding is a pointer to the fact that NCE-trained Social Studies teachers, irrespective of the mode of training, are not too competent in classroom practice because pupils' active participation in the teaching-leaming process is poor. There seems to be a correspondence between this finding and that of Marso and Pigge (1991) who found that trainee teachers who were followed up three consecutive times before and after their training showed no appreciable change in their attitude to teaching.

The finding that teachers do not show adequate competence in teaching Social Studies classes in this study is further confirmed by earlier findings by Oyedeji (1993);Blake and Landsdell (2000); Okwilagwe (2005); Falaye (2007); and Akpan (2008); that there is teacher domination of the teaching-learning process. These scholars reported that teachers often give very little opportunity for students' initiated behaviours and scarcely involve them in the teaching-learning process. Findings in this study also give credence to the assertion by Abe (1998) and Nwaubani (2005) that if pupils are taught and given opportunity to participate in classroom activities, they will learn and retain facts and information better. The finding as it concerns, teacher domination in classroom also implies that these primary school teachers have not complied with the policy that the methods of teaching at this level should be practical, exploratory and experimental. The compliance with the recommended teaching methods in the education policy will 
guarantee more interaction and participation of pupils in the teaching-learning process and eventually lead to better academic achievement of this group of learners.

\section{Conclusion}

Teaching is communication and interaction cannot be devoid of the process of communication. The study strongly contends the indispensability of the teacher in the teaching-learning process and in ensuring that pupils learn and achieve academically. The study, which examined the role of gender and quality of teacher's experience as enabling determinants in the execution of this process, found that the interaction patterns of both NTI NCE and full-time NCE teachers were very similar. It was also observed that both gender and experience did not positively influence teachers' interaction patterns at the set level of significance. Based on the findings of the study, efforts should be made at improving the quality of teaching practice organised for trainee teachers for all types of teacher preparation programmes in the country so as to improve on the competencies of these teachers in the classroom. Teaching practice should not be an exclusive role of Colleges of Education and Faculties of Education alone but a collaborative effort with the Ministry of Education, administrative head, and representatives of teachers in host schools as well as the classroom teachers. There is also need for innovations in pedagogy so that NCE teachers would employ more interactive strategies to facilitate learning in order to attain the objectives of teaching the subject instead of the conventional method of teaching that still pervades the classrooms. Social Studies teachers should encourage openand permissive classroom interactions because it is the whole idea behind functional and resource-based teaching methods which are fundamental to the effective teaching and learning of integrated Social Studiesin Nigerian schools. In order to enhance the effectiveness of Social Studies teachers, trainee Social Studies teachers should be well grounded in pre and post training classroom communication skills that can enhance high quality classroom interactions with students, to enable them learn better. 


\section{References}

Abe, C. V. (1998). A comparative study of student teachers' performance in teaching practice. Journal of Research in Education, 2(1): 72-78.

Adeniji, I. A. (2003). A causal interaction of some teacher variables and students' academic achievement in secondary schools. Journal of Educational Focus, 4: 61-71.

Ajewole, C. A. (1990). Effects of guided discovery and expository instructional methods. Journal of Science Teachers' Association, 26 (2): 32-36.

Akinwumiju, J. A. \& Orimoloye, P. S. (1997). 'Accountability in public examinations: The situation in Nigeria'. In E. Dada (Ed.), Mass failure in public examinations: Causes and problems. (pp. 49-64); Nigeria: Ibadan: Heinemann Educational Books (Nig.) Ltd.

Akpan, O. U. (2008). An Analysis of classroom interaction of senior secondary school chemistry teachers in Ikot Ekpene local government area of Akwa Ibom State, Nigeria, Journal of Science Teachers Association of Nigeria, 43 (1 \& 2): 16-22.

Arends, R. I. (1991) learning to teach ( $2^{\text {nd }}$ Ed.). New York: McGraw- Hill, Inc.

Awoyemi, A. O. (2000). Relationship between classroom interaction and students' academic performance in economics. Unpublished Masters project, University of Ibadan, Ibadan, Nigeria.

Babelan, A. Z. \& Kia, M. (2010). Study of teacher-students. interaction in teaching process and its relation with students' achievement in primary school. The Social Sciences Medwell Journals, 5 (S1): 55-59.

Blake, D. \& Landsdell, F. (2000). Quality in initial teacher education, 8 (2): 63-69. MCB University Press.

Bress, P. (2000).Gender differences in teaching styles. Bureau of Educational and Cultural Affairs. Office of English Language Programs. English Teaching Forum. 38 (4): 1-3. Retrieved online 5/21/2011 from http://eca.stste.gov/forumvols/vol38/no4/p26.htm

Brophy, G. M. (1999). Regardless of sex. The Mathematics Teachers, 74 (2): 261.

Carroll, J. B. (1963). Model of school learning. Teachers College Record, 64: 723-733.

Ebong, J. (2006). Teachers as resources for change and innovation in primary schools. Nigeria Journal of Curriculum Studies, 13: 83-90. 
Ezeasor, M. N. (2005). Teacher effectiveness and teacher gender as determinants of students' achievement in senior secondary school biology in Ogun State. In A.E. Emeke \& C. V. Abe (eds.), Evaluation in theory and practice: A book of reading in honour of Prof. Joseph O. Obemeata (pp. 213-223) Ibadan, Nigeria: Franco-Ola Printers.

Falaye, F. V. (2007). Interaction patterns in junior secondary social studies classroom. Nigerian Journal of Social Studies, X (1 \& 2): 205-218.

Federal Ministry of Education (2007). 9-yers basic education curriculum: Social studies for primary 4-6. Abuja, NERDC Press.

Federal Republic of Nigeria (2004). National policy on education, (4th edition). Yaba, Lagos: NERDC Press.

Flanders, N. A. (1970). Analyzing teaching behavior. Massachusetts: Addison - Wesley Publishing Company.

Isiugo-Abanihe, I. M. (2004). Measurement constraints and advances in improving the quality of observational instruments. In O. Afemikhe \& J. G. Adewale (Eds.).Issues in educational measurement and evaluation in Nigeria (pp. 349-357) Educational Research and Study Group, Institute of Education, University of Ibadan, Ibadan, Nigeria.

Labo-Popoola, S.O. (2002). Teacher and school variables as determinants of students' achievement in comprehension and summary writing aspects of English Language. Unpublished PhD Thesis University of Ibadan, Ibadan.

Linda, D. (2000). Teachers' quality and student achievement: A review of state policy evidence in Glass (Ed.) Electronic Journal on Educational Policy Analysis Archives, 8 (1): $1-50$.

Kiadese, A. L. (2011). An assessment of the teaching effectiveness of prevocational subjects teachers in Ogun State Nigeria. International Journal of Vocational and Technical Education, 3 (1): 5-8.

Marso, R. N. \& Pigge, F. L. (1991). Factors associated with longitudinal changes in teachers' attitude toward teaching during training and the first year of training. Presented at the Annual Meeting of the Association of Teacher Educators. $71^{\mathrm{st}}$, New Orleans, LA, Feb.16-18, 1991.

Moyer, C. (1978). The relationship between mathematical structure of Euclidean transformations and the spontaneously developed cognitive structures of young children. Journal of Research in Mathematics Education, 19 (7).

Mezeiobi, K.A. (2000). Social studies teaching methods and teaching in G.W. Joof \& H.C. Amadi (Eds.) Social studies in school: Teaching methods, techniques, approaches and perspective (pp 85-88) Onitsha, Nigeria: Out rites Publishers. 
Mkpa, M. A. (1997). Evolving the concept of social studies. In D. D. Meziobi \&O.M. Philips (Eds.) Readings in Social Studies Education (Pp1-11) Owerri, Nigeria: Canon Publishers Ltd.

Nwaubani, O. O. (2005). Evaluating social studies curriculum for instructional efficiency in Nigerian schools and colleges. In A.E. Emeke \&C.V. Abe (Eds.), Evaluation in theory and practice: A book of reading in honour of Prof. J. O. Obemeata (pp 107-121) Ibadan, Nigeria: Franco-Ola Printers.

Odinko, M. N. \& Williams, J. M. (2006). Language of instruction and interaction patterns at the pre-primary level of education in Nigeria. Journal of Classroom Interaction, 26 (1): 22-32.

Ogunkola, B. J. (1999). Interaction pattern in primary school science classroom in IjebuOde, Ogun State. African Journal of Education Research, 5 (1): 51-61.

Ogunyemi, B. (2000). Concepts in teaching and teaching methods. In S.Y. Erinosho; A. Adesanya \& B. Ogunyemi (Eds.), Teaching effectiveness in Nigerian schools (pp 3-16) Ibadan, Nigeria: Sam Bookman Publishers.

Ojo, G. O. (2006). Relationship between teachers' characteristics and students' academic performance in secondary schools in Ogun State, Nigeria. Journal of Educational Focus, 7: 74-86.

Okpala, P. N. \& Onocha, C. O. (1988). Classroom interaction patterns: Nigerian physics teacher trainees. Physics Education: A Journal of the British Institute of Physics, 23 (5): 288-290.

Okpala, P. N. (1999). Evaluation of teaching effectiveness. In J. O. Obemeata; S.O. Ayodele \& M. A. Araromi (Eds.), Evaluation in Africa in Honour of Prof. E. A. Yoloye (pp. 72-82). Ibadan, Nigeria: Stirling-Horden Publishers (Nig.) Ltd.

Okwilagwe, E. A. (2005). Evaluating the private-public school dichotomy: The missing link. In A.E. Emeke \&C.V. Abe (Eds.). Evaluation in theory and practice: A book of reading in honour of Prof. J. O. Obemeata (pp123-140). Ibadan, Nigeria: Pen Services.

Okwilagwe, E. A. \& Samuel, E. O. (2011). Students' evaluation of social studies teachers' effectiveness in selected junior secondary schools in Oyo State. African Journal of Educational Research, 15 (1 \& 2): 1-12

Oloyede, D. O. \& Amosuro, O. Y. (2006). Teachers' qualification and experience as predictors of their job performance. Journal of Educational Focus, 7: 1-12.

Onocha, C. O. \& Okpala, P. N. (1995). Tools for educational research. Ibadan: Stirling Horden Publishers (Nig.) Ltd.

Oyedeji, O. A. (1993). A survey of mathematics classroom verbal interaction patterns in selected junior secondary schools in Ogun State, Nigeria. Ogun State University Journal of Educational Studies, 2 (2): 1-11. 
Oyekan, S. O. (2000). Foundations of teachers' education. Okiti-Pupa, Ondo State: Ebun Ola Printers (Nig.) Limited.

Yoloye, E. A. (1977). Observational techniques. In A. Lewy (Ed.) Handbook of Curriculum Evaluation. Paris: Longman.

Yusuf, A. (2004). Effect of Cooperative and Competitive Instructional Strategies on Junior Secondary School Students' Performance in Social Studies, in Ilorin, Nigeria. Unpublished PhD Thesis, University of Ilorin, Ilorin. 